\title{
MDM2 Inhibitor BI 907828
}

National Cancer Institute

\section{Source}

National Cancer Institute. MDM2 Inhibitor BI 907828. NCI Thesaurus. Code C156709.

An orally available inhibitor of murine double minute 2 (MDM2), with potential antineoplastic activity. Upon oral administration, BI 907828 binds to MDM2 protein and prevents its binding to the transcriptional activation domain of the tumor suppressor protein p53. By preventing MDM2-p53 interaction, the transcriptional activity of p53 is restored. This leads to p53-mediated induction of tumor cell apoptosis. Compared to currently available MDM2 inhibitors, the pharmacokinetic properties of BI 907828 allow for more optimal dosing and dose schedules that may reduce myelosuppression, an ontarget, dose-limiting toxicity for this class of inhibitors. 